\title{
A Patient of Hypogonadotropic Hypogonadism Accompanied by Growth Hormone Deficiency and Decreased Bone Mineral Density Who Attained Normal Growth
}

\author{
Seiki Wada, Akinobu Minagawa, Keiji Imamaki, Satoru Suda, Kayo Yamanaka, \\ Makoto IITAKa and Shigehiro KatAYAma
}

\begin{abstract}
We present here a rare case of hypopituitarism accompanied by growth hormone (GH) deficiency and hypogonadotropic hypogonadism, in which the patient attained normal height but was of eunuchoid appearance. A 23-year-old man who had not reached puberty was referred to Saitama Medical School for hormonal evaluation. Basal hormonal data and hormone-stimulating tests revealed impaired secretion of GH, gonadotropins and adrenocorticotropic hormone (ACTH). Serum levels of testosterone, estrone, estradiol and estriol were all below the detectable ranges. The patient's plasma ACTH responded to corticotropin releasing hormone, but not to insulin-induced hypoglycemia. Serum GH showed a minimal response to GHreleasing hormone, but was unresponsive to insulin-induced hypoglycemia. Serum luteinizing hormone and follicle stimulating hormone did not respond to luteinizing hormone-releasing hormone. The results were compatible with a diagnosis of hypothalamic hypopituitarism. Magnetic resonance images of the brain showed a small anterior pituitary, an ectopic posterior lobe and transection of the pituitary stalk. Although the patient showed signs of hypopituitarism, he finally attained normal height, possibly because of failed epiphyseal maturation. His bone mineral density was markedly reduced to $0.647 \mathrm{~g} / \mathrm{cm}^{2}$ in the lumbar spine; this level was $61.7 \%$ of the average level of healthy young males. Our findings were compatible with a recently advocated view that estrogen is important in promoting epiphyseal fusion and in determining bone density in males as well as females.

(Internal Medicine 39: 641-645, 2000)
\end{abstract}

Key words: hypopituitarism, adrenocorticotropic hormone deficiency, estrogen, androgen, pituitary stalk, osteoporosis

\section{Introduction}

Short stature or dwarfism is one of the characteristics of congenital disorders of the hypothalamus and pituitary (1). A deficiency of growth hormone $(\mathrm{GH})$ secretion is generally associated with reduced height as well as hypothyroidism. In patients with thyroid hormone deficiency, severe growth failure and arrest occurs. Although it is well known that GH plays a critical role in normal growth, some patients with GH deficiency or hypopituitarism are reported to attain normal or even tall stature $(2,3)$. This mechanism remains to be fully elucidated. Along with the short stature, hypogonadotropic hypogonadism is frequently accompanied by congenital pituitary disorders; male patients show decreased androgen levels and failure of spermatogenesis (1). It has been speculated that deficiency of sex steroids (estrogen in the female and androgen in the male) causes failure of epiphyseal maturation (4). Recently, however, male patients with aromatase deficiency clearly showed that estrogen was primarily important in determining epiphyseal maturation in males as well as in females $(5,6)$. During young adulthood, the skeleton acquires all the bone mineral content it will ever have (7). Therefore, failure to achieve optimum peak bone mass and the resulting deranged bone strength or architecture in later life could be a pathogenic mechanism of osteoporosis (8). Although it has been believed that androgens are primary determinants of bone mineral content in males, several lines of evidence suggest that estrogen deficiency is responsible for the pathogenesis of osteoporosis not only in females, but also in males $(5,6,9,10)$. Estrogen supplements given to an aromatase deficient male resulted in a marked increase of bone mineral density (BMD) (11). These observations could indicate that androgen alone is not sufficient to promote skeletal maturation and retain bone mineral content in males. In this report we present a rare case of hypopituitarism, in which the patient attained normal height with impaired GH secretion, unfused epiphyseal growth plates and low BMD; the last two signs appeared to be associated with

From the Fourth Department of Internal Medicine Saitama Medical School, Saitama

Received for publication October 14, 1999; Accepted for publication March 9, 2000

Reprint requests should be addressed to Dr. Seiki Wada, the Fourth Department of Internal Medicine, Saitama Medical School, 38 Morohongo, Moroyama-cho, Iruma-gun, Saitama 350-0495, email: wadas@saitama-med.ac.jp 
estrogen deficiency.

\section{Case Report}

A 23-year-old man was referred to Saitama Medical School Hospital for evaluation and treatment of hypopituitarism. He had been well until three months before admission when he had been hospitalized with pneumonia. During hospitalization, his eunuchoid appearance and sexual infantilism were noticed. Since his basal hormonal data were compatible with hypopituitarism, he was referred to our department for further evaluation. His birth had been uncomplicated but in breech presentation. His weight at birth had been $3.38 \mathrm{~kg}$. There was no history of neonatal hypoglycemia, birth asphyxia or prolonged jaundice. Although he was the shortest in his class throughout his school days, he had still grown steadily (Fig. 1) and had attained a height of $174.5 \mathrm{~cm}$ by age 23 .

Physical examination revealed a eunuchoid appearance, an immature face and an immature, high-pitched voice. The patient weighted $79.2 \mathrm{~kg}$. Blood pressure was $118 / 66 \mathrm{mmHg}$. The characteristics of puberty were absent: there was no axillary or pubic hair, and he had stage I (preadolescent) genital development (12). No pigmentation was observed in his skin or mucosa. He was alert and had no focal neurological signs. His intelligence was normal according to intelligence testing. His sense of smell and level of thirst were not disturbed. His hands

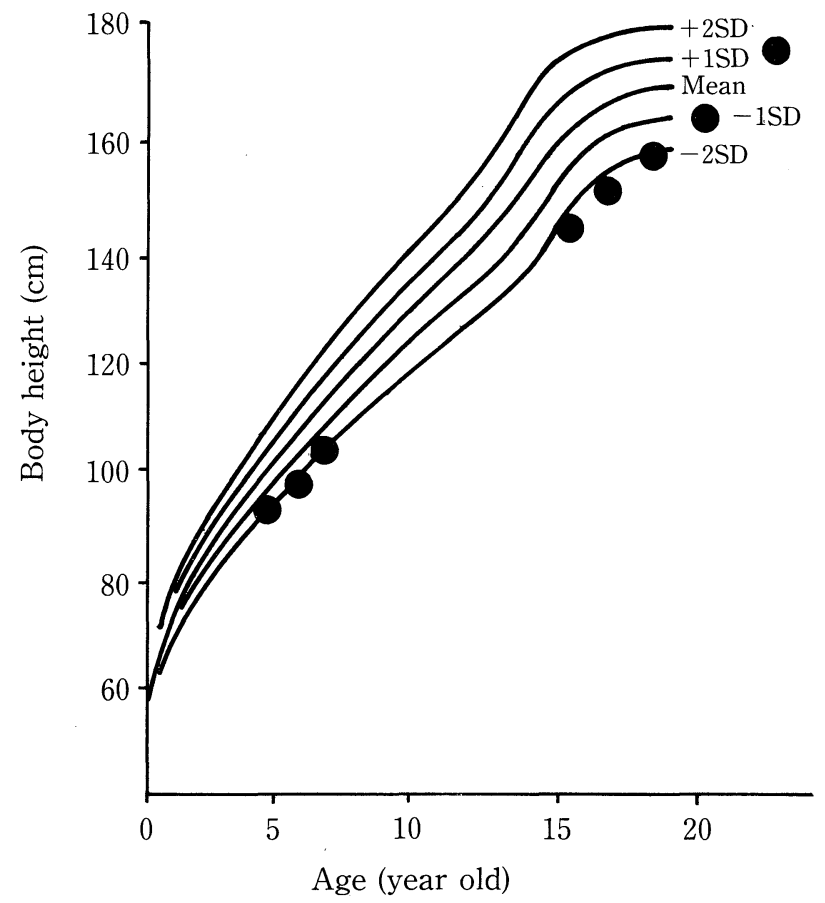

Figure 1. Growth chart of Japanese boys and the case presented. Body height of the present case is shown by closed circles. Sources of data: 1990 standard growth charts for height of Japanese children from birth to 17 years based on a cross-sectional survey of Japan (27). and feet were extremely large, compared with his whole body size: his feet were $30 \mathrm{~cm}$ long, and his arm span was $173 \mathrm{~cm}$.

Radiological examination showed that the epiphyseal lines in the patient's limbs were still unclosed, and his bone age corresponded to a chronological age of 14 year (13). The BMD of his lumbar spine was extremely low at $0.647 \mathrm{~g} / \mathrm{cm}^{2}$, this figure was $61.7 \%$ of the mean BMD of young Japanese male adults (20-40 year). The patient's chromosome pattern was 46XY. Biochemical examination showed an elevated total cholesterol level $(296 \mathrm{mg} / \mathrm{dl})$. The serum phosphate and alkaline phosphatase levels were elevated to $4.5 \mathrm{mg} / \mathrm{dl}$ (normal range: 2.4 4.4) and $413 \mathrm{IU} / \mathrm{l}$ (normal range: 96-284), respectively. The elevated ALP level was consistent with the bone maturation age. The levels of other serum electrolytes were within the normal ranges. Autoantibodies to anterior pituitary cells were not detected.

The serum GH level was less than $0.1 \mathrm{ng} / \mathrm{ml}$, and levels of IGF-1 and IGFBP-3 were reduced (Table 1). As shown in Table 2, GH responses to GRH were minimal and GH responses to insulin-induced hypoglycemia were completely absent (insulin $0.05 \mathrm{U} / \mathrm{kg}$ body weight). Serum levels of testosterone, estrone, estradiol, estriol and dehydroepiandrosterone-sulfate (DHEA-S) were all extremely low. The basal values of both serum luteinizing hormone (LH) and follicle-stimulating hormone (FSH) were low. These hormones did not respond to intravenous administration of LH-RH (Table 2). The basal levels of plasma adrenocorticotropin (ACTH) and cortisol were low. ACTH responded to injection of human corticotropin-releasing hormone (CRH), but not to insulin-induced hypoglycemia. Urinary excretion of 17-ketosteroids and 17hydroxycorticosteroids was reduced. Although the basal value of serum thyrotropin (TSH) was within the reference range, $\mathrm{fT}_{3}$ and $\mathrm{fT}_{4}$ concentrations were below the reference ranges. Serum TSH and prolactin (PRL) responded normally to TSHreleasing hormone (TRH). Urinary osmotic pressure (420 $\left.\mathrm{mOsm} / \mathrm{kgH}_{2} \mathrm{O}\right)$ and urine volume $(\sim 1,200 \mathrm{ml} /$ day $)$ were within the normal range. Magnetic resonance imaging (MRI) of the brain showed transection of the pituitary stalk, a small anterior pituitary and an ectopic posterior lobe at the proximal stump of the pituitary stalk (Fig. 2).

Under a diagnosis of hypopituitarism the patient received replacement therapy with hydrocortisone $(20 \mathrm{mg}$ per day) and levothyroxine sodium ( $25 \mu \mathrm{g}$ per day) orally. Administration of levothyroxine sodium raised the levels of $\mathrm{fT}_{4}$ and $\mathrm{fT}_{3}$ to within the reference ranges, and the TSH level remained within its reference range. For the hypogonadotropic hypogonadism, the patient was scheduled to receive testosterone enanthate intramuscularly, as well as supplements of human chorionic gonadotropin and human menopausal gonadotropin.

\section{Discussion}

GH deficiency caused by tumors of the hypothalamus-pituitary in young results in late onset growth failure, while patients with congenital GH deficiency show early manifestation of growth retardation (14). It is known that even without go- 
Table 1. Basal Endocrinological Data

\begin{tabular}{lrc}
\hline & \multicolumn{1}{c}{ Values } & Reference range \\
\hline Growth hormone (GH) & $<0.1 \mathrm{ng} / \mathrm{ml}$ & $<5.0$ \\
Thyroid-stimulating hormone (TSH) & $3.88 \mu \mathrm{U} / \mathrm{ml}$ & $0.43-3.94$ \\
Luteinizing hormone (LH) & $<0.1 \mathrm{mIU} / \mathrm{ml}$ & $1.8-8.3$ \\
Follicle-stimulating hormone (FSH) & $0.4 \mathrm{mIU} / \mathrm{ml}$ & $1.6-11.0$ \\
Adrenocorticotropin (ACTH) & $8 \mathrm{pg} / \mathrm{ml}$ & $6.0-36.0$ \\
Prolactin (PRL) & $21.9 \mathrm{ng} / \mathrm{ml}$ & $2.7-16.8$ \\
Vasopressin & $1.3 \mathrm{pg} / \mathrm{ml}$ & $0.8-6.3$ \\
Insulin-like growth factor (IGF) 1 & $20.5 \mathrm{ng} / \mathrm{ml}$ & $106-398$ \\
IGF binding protein 3 & $1.32 \mu \mathrm{g} / \mathrm{dl}$ & $1.90-3.89$ \\
Free tri-iodothyronine (fT ${ }_{3}$ ) & $2.41 \mathrm{pg} / \mathrm{ml}$ & $3.14-4.93$ \\
Free thyroxine (fT ${ }_{4}$ ) & $0.54 \mathrm{ng} / \mathrm{dl}$ & $0.82-1.59$ \\
Thyroperoxidase antibody & $<0.3 \mathrm{U} / \mathrm{ml}$ & $<0.3$ \\
Thyroglobulin antibody & $<0.3 \mathrm{U} / \mathrm{ml}$ & $<0.3$ \\
Serum cortisol & $1.0 \mu \mathrm{g} / \mathrm{dl}$ & $3.0-15.2$ \\
Urine 17-ketosteroids (KS) & $0.1-0.8 \mathrm{mg} / \mathrm{day}$ & $4.2-12.4$ \\
Urine 17-hydroxycorticosteroids (OHCS) & $1.3-7.6 \mu \mathrm{gg} / \mathrm{dl} *$ & $3.1-8.7$ \\
testosterone & $<5 \mathrm{ng} / \mathrm{ml}$ & $320-1,030$ \\
estrone (E ${ }_{1}$ ) & $<10 \mathrm{pg} / \mathrm{ml}$ & $28-102$ \\
estradiol (E ${ }_{2}$ ) & $<10 \mathrm{pg} / \mathrm{ml}$ & $12-49$ \\
estriol (E E $_{3}$ ) & $<10 \mathrm{pg} / \mathrm{ml}$ & $<10$ \\
Dehydroepiandrosterone sulfate (DHEA-S) & $138 \mathrm{ng} / \mathrm{ml}$ & $1,300-5,600$ \\
\hline
\end{tabular}

*The values of $17 \mathrm{OHCS}$ were measured under supplementation of $10 \mathrm{mg}$ hydrocortisone acetate orally.

Table 2. Anterior Pituitary Function Tests

\begin{tabular}{ccccccc}
\hline & & \multicolumn{5}{c}{ Time } \\
\cline { 3 - 6 } & & 0 & 15 & 30 & 60 & $90 \mathrm{~min}$ \\
\hline CRH test & & & & & & \\
ACTH & $\mathrm{pg} / \mathrm{ml}$ & 18 & 61 & 51 & 39 & 34 \\
Cortisol & $\mu \mathrm{g} / \mathrm{dl}$ & $<1.0$ & 4.5 & 4.9 & 3.6 & 4 \\
TRH test & & & & & & \\
TSH & $\mu \mathrm{U} / \mathrm{ml}$ & 2.69 & 9.4 & 14 & 14.6 & 11 \\
PRL & $\mathrm{ng} / \mathrm{ml}$ & 18.8 & 38.9 & 48.4 & 40.9 & 28.5 \\
LH-RH test & & & & & & \\
LH & $\mathrm{mIU} / \mathrm{ml}$ & $<0.1$ & $<0.1$ & 0.1 & 0.1 & 0.1 \\
FSH & $\mathrm{mIU} / \mathrm{ml}$ & 0.5 & 0.9 & 1.0 & 1.0 & 1.0 \\
GRH test & & & & & & \\
GH & $\mathrm{ng} / \mathrm{ml}$ & 0.1 & 1.4 & 1.8 & 1.2 & 0.8 \\
\hline Insulin test & & & & & & \\
Glucose & $\mathrm{mg} / \mathrm{dl}$ & 73 & 41 & 21 & 37 & \\
GH & $\mathrm{ng} / \mathrm{ml}$ & $<0.1$ & $<0.1$ & $<0.1$ & $<0.1$ & \\
ACTH & $\mathrm{pg} / \mathrm{ml}$ & 14 & 9 & 12 & 11 & \\
Cortisol & $\mu \mathrm{g} / \mathrm{dl}$ & $<0.1$ & $<0.1$ & $<0.1$ & $<0.1$ & \\
\hline
\end{tabular}

Anterior pituitary hormones and cortisol responses were assessed by administration of CRH $(100 \mu \mathrm{g})$, TRH $(500 \mu \mathrm{g})$, LH-RH $(100 \mu \mathrm{g})$, GRH $(100 \mu \mathrm{g})$ and insulin $(0.05 \mathrm{U} / \mathrm{kg})$. CRH: corticotropin-releasing hormone, GRH: growth hormone-releasing hormone, LH-RH: LH-releasing hormone, TRH: thyrotropin-releasing hormone. nadotropin deficiency, untreated patients who are GH-deficient show delayed onset of puberty. With appropriate $\mathrm{GH}$ replacement, however, the onset of puberty occurs at the normal age (15). In the present patient, hypothalamic-pituitary function tests revealed impaired secretion of GH. Nevertheless, the patient had shown slow but continuous linear growth, and had obtained normal Japanese male height after adolescence, although he had been short throughout his school days. The present case raises an intriguing possibility that, under certain conditions, males are able to grow at an almost steady rate without $\mathrm{GH}$ secretion. Similar to this case, Kageyama et al (2) reported a patient with a pituitary stalk transection who grew tall in the absence of GH secretion. They speculated that potent growthpromoting factor(s) other than GH and IGF-1 could be important in determining height. In addition to impaired GH secretion, their patient and the present case had hypogonadotropic hypogonadism. The absence of sex steroids in these cases prevented a pubertal growth spurt, but still permitted continued linear growth. Although these patients had reduced serum levels of testosterone, their phenotypes may have been attributable to the absence of estrogenic effects, since linear growth after adolescence has been observed in patients deficient in estrogenic action $(5,6,10)$. A deficiency of sex steroids (estrogen in the female and androgen in the male) has been reported to induce a failure of epiphyseal maturation (4). Further, recent studies of patients with aromatase deficiency have shown that estrogen is of primarily importance in the maturation of epiphyses in males as well as in females $(5,6)$. 

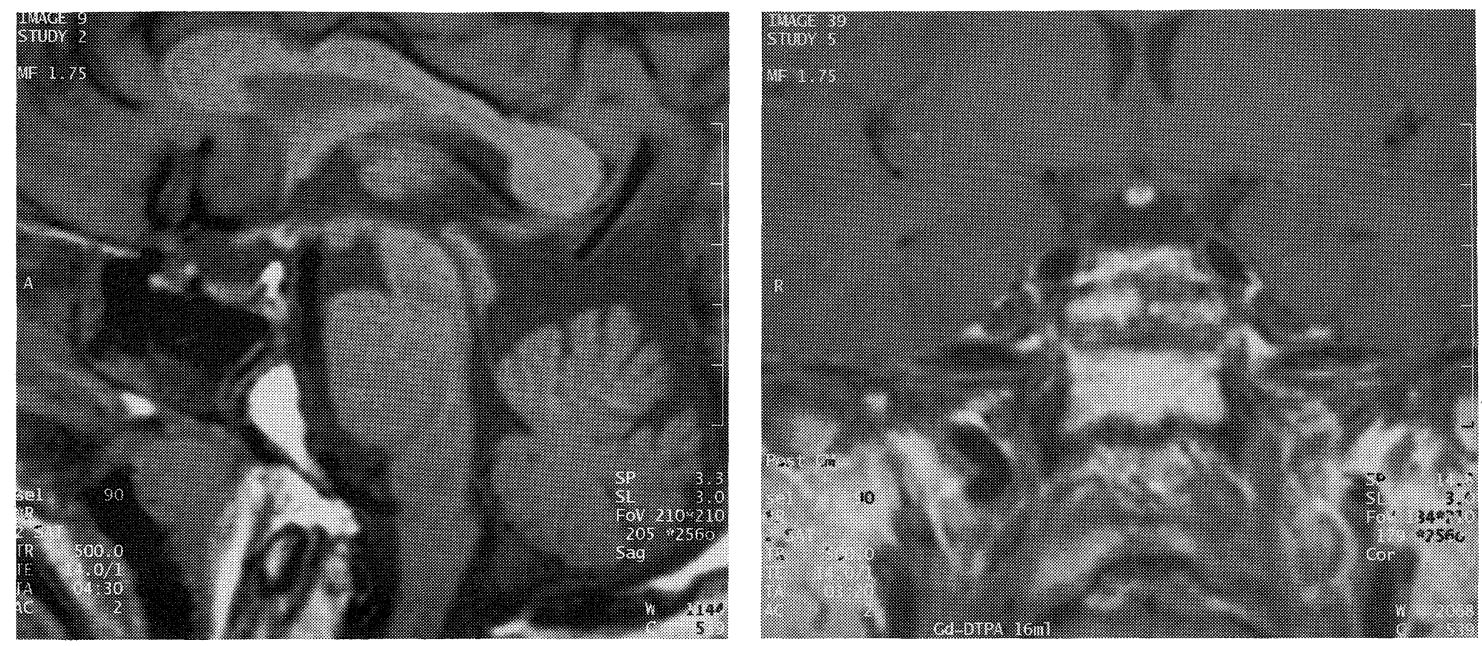

Figure 2. Images of brain magnetic resonance in this case. Midsagittal and frontal $\mathbf{T}_{1}$-weighted images show a transection of the pituitary stalk, a small anterior pituitary and an ectopic posterior lobe at the proximal stump of the pituitary stalk.

It is recognized that a rise in serum TSH after repetitive TRH administration suggests hypothalamic hypothyroidism. However, considerable overlap has been reported between pituitary and hypothalamic forms of central hypothyroidism (16). TSH secretion can be impaired not only quantitatively, but also qualitatively: TSH secreted in response to exogenous TRH was biologically inactive in some cases of hypothalamic hypothyrodism (17). In our patient, the elevated level of serum cholesterol $(296 \mathrm{mg} / \mathrm{dl})$ dropped to $263 \mathrm{mg} / \mathrm{dl}$ after replacement therapy with levothyroxine $25 \mu \mathrm{g} / \mathrm{day}$, which indicates that the hypothyroidism would be associated with hypercholesterolemia. GH deficiency and hypogonadotropic hypogonadism, however, might also be associated with the hypercholesterolemia. Although we were unable to perform the LH-RH test after daily administration of LH-RH, the impaired response of GH and ACTH to hypoglycemia and the delayed responses of TSH and PRL to TRH administration suggested a diagnosis of hypothalamic hypopituitarism. This diagnosis was supported by the finding of a transected pituitary stalk on MRI. It is well known that insulin-induced hypoglycemia activates hypothalamic neurons to stimulate pituitary secretion of ACTH and GH (18). The elevated basal PRL values observed in the present patient could be related to a possible impairment of hypothalamic inhibitory regulation of PRL secretion, rather than to primary hypothyroidism, since in primary hypothyroidism there is an enhanced response of PRL to TRH.

Studies of osteoporosis in humans and animals with mutations of the estrogen receptor gene and in patients with aromatase deficiency have underlined the importance of estrogens in skeletal maturation $(5,6,11)$. It has been recognized that the male skeleton accumulates more mineral density than the female skeleton because of its greater exposure to androgens (19). However, it appears that both androgens and estrogens are important, and that, together, they are critical deter- minants of peak mass in the male skeleton. Studies in male rats have shown that both androgens and estrogens are required for optimum skeletal maturation (20). One male patient with estrogen resistance caused by estrogen receptor mutation was found to have a severely undermineralized skeleton with biochemical evidence of increased bone resorption (10). Estrogen supplements given to an aromatase-deficient male induced maturation of bone mineral contents and increased BMD. These studies indicate that estrogen is important in establishing bone mineral content in males. In addition, it was shown recently that the slow age-related decline in BMD in males is more directly related to declining estrogen levels than to declining androgen levels (9). These observations would indicate that the presence of androgen alone is not sufficient to promote skeletal maturation and retain bone mass and that estrogen has a central role in mineralization of the skeleton in males as well as in females. Although a bone biopsy was not performed on the present patient, the BMD of his lumbar spine was very low compared with those of healthy young male adults. In addition to hypogonadotropic hypogonadism, the patient had an impaired ACTH-cortisol axis. His reduced level of DHEA-S would suggest a limited supply of adrenal androgens, which in healthy subjects can be converted to estrogens with the aid of aromatase in peripheral tissues. The limited supply of adrenal androgens would further reduce the patient's serum levels of estrogen.

As has been commonly observed in congenitally GH-deficient patients (21), the present patient had a small anterior pituitary, an ectopic posterior lobe and a transection of the pituitary stalk. Fujisawa et al (22) have proposed that trauma occurring at the time of delivery may transect the pituitary stalk, leading to a hypoplastic anterior pituitary and regeneration of the distal axons of the hypothalamus to form an ectopic posterior pituitary located at the bottom of hypothalamus. However, 


\section{Normal Growth with GH}

there are a number of lines of evidence against this trauma theory: quite a few patients with GH deficiency and an ectopic posterior pituitary gland are born either in the vertex position or by cesarean section, and a high incidence of associated anomalies, such as micropenis and cryptorchidism, has been observed in these patients (23). Although our patient was delivered by breech presentation, there was no evidence of trauma during the delivery. As hypothesized by Hamilton et al (24), congenital genetic defects, especially in the hypothalamus and pituitary, should be re-considered in terms of fetal positioning. Recently, various factors or genes responsible for the development of hypothalamus-pituitary, e.g. Pit 1 and Ames dwarf, have been isolated, and the functions of these genes have been eagerly investigated $(25,26)$. In the future, better knowledge of these genotype-phenotype relationships might clarify the close relationship between congenital pituitary disorders and fetal positioning in the uterus.

In summary, we have reported an unusual case of GH deficiency in which the patient attained normal height with unfused epiphyses because of hypogonadotropic hypogonadism. This case suggests that males can grow without GH under certain circumstances. The reduced peak bone mass and the lack of epiphyseal closure seen in this case may be associated with estrogen depletion.

\section{References}

1) Grumbach MM, Styne DM. Puberty: ontogeny, neuroendocrinology, physiology, and disorders. in: Williams Textbook of Endocrinology. Wilson JD, Foster DW, Kronenberg HM, Larsen PR Eds., WB Saunders Company, Philadelphia, 1998: 1509-1625.

2) Kageyama $K$, Watanabe H, Nasushita R, Nishie M, Horiba N, Suda T. A hypopituitary patient who attained tall stature without growth hormone. Inter Med 37: 472-475, 1998.

3) Geffner ME, Lippe BM, Bersch N, et al. Growth without growth hormone: evidence for a potent circulating human growth factor. Lancet. 1: 343-347, 1986.

4) Braunstein GD. Evaluation of male gonadal function. in: Basic and Clinical Endocrinology. Greenspan FS Ed., Appeleton and Lange, Connecticut, 1991: 413-420.

5) Carani C, Qin K, Simoni M, et al. Effect of testosterone and estradiol in a man with aromatase deficiency. N Engl J Med 337: 91-95, 1997.

6) Morishima A, Grumbach MM, Simpson FR, Fisher C, Qin K. Aromatase deficiency in male and female siblings caused by a novel mutation and the physiological role of estrogens. J Clin Endocrinol Metab 80: 36893698, 1995.

7) Bonjour JP, Rizzoli R. Bone acquisition in adolescence. in: Osteoporosis. Marcus R, Feldman D, Kelsey J Eds, Academic Press, San Diego, 1996: 465-480.

8) Finkelstein JS, Neer RM, Biller BM, Crawford JD, Klibanski A. Osteopenia in men with a history of delayed puberty. N Engl J Med 326: 600-604, 1992.

9) Slemenda CW. Longcope C. Zhou L, Hui SL, Peacock M, Johnston CC. Sex steroids and bone mass in older men. Positive associations with se- rum estrogens and negative associations with androgens. J Clin Invest 100: 1755-1759, 1997.

10) Smith EP, Boyd J, Frank GR, et al. Estrogen resistance caused by a mutation in the estrogen-receptor gene in a man. N Engl J Med 331: 10561061, 1994 (published erratum appears in N Engl J Med 332: 131, 1995).

11) Bilezikian JP, Morishima A, Bell J, Grumbach MM. Increased bone mass as a result of estrogen therapy in a man with aromatase deficiency. $\mathrm{N}$ Engl J Med 339: 599-603, 1998.

12) Marshall WA, Tanner JM. Variations in the pattern of pubertal changes in boys. Arch Dis Child 45: 13-23, 1970.

13) Bone Maturation Study Group. The Atlas of Japanese Standard Bone Maturation. Kinbara Publishing Co. Ltd., Tokyo, 1993: 8 (in Japanese).

14) Thorner MO, Vance ML, Lawa ER Jr, Horvath E, Kovacs K. The anterior pituitary, in: Williams Textbook of Endocrinology. Wilson JD, Foster DW, Kronenberg HM, Larsen PR Eds, WB Saunders Company, Philadelphia, 1998: 249-340.

15) Zadik Z, Chalew SA. Zung A, Lieberman E, Kowarski AA. Short stature: new challenges in growth hormone therapy. J Pediatr Endocrinol 6: 303 310, 1993.

16) Martino E, Bartalena L, Faglia G, Pinchera A. Central hypothyroidism. in: Werner and Ingbar's The Thyroid. Braverman LE, Utiger RD Ed, Lippincott-Raven Publishers, Philadelphia, 1995: 779-791.

17) Beck-Peccoz P, Amr S, Menezes-Ferreira MM, Faglia G, Weintraub BD. Decreased receptor binding of biologically inactive thyrotropin in central hypothyroidism: effect of treatment with thyrotropin-releasing hormone. N Engl J Med 312: 1085-1090, 1985.

18) Landon J, Greenwood FC, Stamp TC, Wynn V. The plasma sugar, free fatty acid, cortisol, and growth hormone response to insulin, and the comparison of this procedure with other tests of pituitary and adrenal function. II: In patients with hypothalamic or pituitary dysfunction or anorexia nervosa. J Clin Invest 45: 437-449, 1966.

19) Vanderschueren D, Bouillon R. Androgens and bone. Calcif Tissue Int 56: 341-346, 1995.

20) Vanderschueren D, van Herck E, Nijs J, Ederveen AG, De Coster R, Bouillon R. Aromatase inhibition impairs skeletal modeling and decreases bone mineral density in growing male rats. Endocrinology 138: 2301-2307, 1997.

21) Arrigo T, De Luca F, Maghnie M, et al. Relationships between neuroradiological and clinical features in apparently idiopathic hypopituitarism. Eur J Endocrinol 139: 84-88, 1998.

22) Fujisawa I, Kikuchi K, Nishimura K, et al. Transection of the pituitary stalk: Development of an ectopic posterior lobe assessed with MR imaging. Radiology 165: 487-489, 1987.

23) Maghnie M, Triulzi F, Larizza D, et al. Hypothalamic-pituitary dwarfism: Comparison between MR imaging and CT findings. Pediatr Raiol 20: 229-235, 1990.

24) Hamilton J, Chitayat D, Blaser S, Cohen LE, Philips III JA, Daneman D. Familial growth hormone deficiency associated with MRI abnormalities. Am J Med Genet 80: 128-132, 1998.

25) Gage PJ, Brinkmeier ML, Scarlett LM, Knap LT, Camper SA, Mahon KA. The ames dwarf gene, df, is required early in pituitary ontogeny for the extinction of $R p x$ transcription and initiation of lineage-specific cell proliferation. Mol Endocrinol 10: 1570-1581, 1996.

26) Tatsumi $K$, Miyai M, Notomi $T$, et al. Cretinism with combined growth hormone deficiency caused by mutation in the Pit-1 gene. Nat Genet 1: 56-58, 1992.

27) Suwa $S$, Tachibana K. Standard growth charts for height and weight of Japanese children from birth to 17 years based on a cross-sectional survey of national data. Clin Pediatr Endocrinol 2: 87, 1993 